\title{
PEMANTAUAN KUALITAS UDARA PADA SEKOLAH DASAR PINGGIR JALAN PERKOTAAN MENGGUNAKAN EPIPHYTIC LICHEN
}

\author{
Sumarlin ${ }^{1)}$, Mochammad Assiddieq ${ }^{2)}$ \\ ${ }^{1)}$ Teknik Lingkungan Universitas Muhammadiyah Kendari; \\ e-mail: ${ }^{1)}$ sumarsultra@gmail.com
}

\begin{abstract}
ABSTRAK
Penelitian ini bertujuan mengetahui pengaruh tingkat kepadatan lalu lintas pada dengan karakteristik makroskopis epiphytic lichen kaitannya dengan kualitas udara di sekolah yang terletak dipinggir jalan. Dalam penelitian didapatkan volume lalulintas harian tertinggi di SDN Poasia sebanyak 8.065 kend/hari, di SDN 2 Baruga sebanyak 7.948 kend/hari dan di SDN 18 Baruga sebanyak 366 kend/hari sedangkan kehadiran ephypitic lichen persentase kehadiran ephypitic lichen tertinggi di SDN 18 Baruga sebanyak 90\% dengan warna talus cerah dan tebal, sedangkan pada SDN 2 Baruga 67\% dan SDN 1 Poasia 66\% dengan warna talus kusam dan tipis. Uji Spearman's rank correlation didapatkan $r_{s}=-1,00$ dan $P_{\text {value }}(0,0) ; P_{\text {value }}(0,0)<\alpha(0,01)$ maka $H_{0}: \rho_{s}=0$ ditolak, artinya semakin tinggi volume lalulintas maka persentase kehadiran lichen semakin rendah. Gas buang kendaraan bermotor yang intens dan periodik memungkinkan menurunnya prosentase kehadiran dan warna epiphytic lichen, hal ini berkaitan erat dengan penurunan kualitas udara di sekolahsekolah pinggir jalan. Berdasarkan karakteristik tampakan epiphytic lichen di lokasi pemantauan menunjukkan lingkungan SDN 1 Poasia dan SDN 2 Baruga telah telah tercemar sedang sedang dan berpotensi tercemar berat sedangkan pada lingkungan SDN 18 Baruga masih pada taraf lingkungan bersih dan berpotensi tercemar ringan.
\end{abstract}

Kata kunci: Epiphytic Lichen, Kualitas Udara, Pemantauan, Sekolah Dasar 


\section{PENDAHULUAN}

Pembangunan sosial ekonomi telah mendorong meningkatnya stok kendaraan bermotor dalam tiap tahunnya. Kepemilikan kendaraan pada dasarnya dipengaruhi harga yang terjangkau, iklan, gaya hidup, pekerjaan, situasi ekonomi konsumen, kelas sosial (Saputra, 2013; Indayani, 2014; Winarti, 2015). Melonjaknya jumlah kendaraan menciptakan sejumlah tantangan substansial seperti kerawanan energi, polusi udara dan kesehatan masyarakat di berbagai negara. Dalam skala global paling tidak emisi kendaraan bermotor bertanggungjawab terhadap meningkatnya 29\% NOx antropogenik di China (MEP, 2014), 37\% di Amerika Serikat (US EPA, 2014 ), dan 40\% di Uni Eropa (EEA, 2014).

Dampak paparan polusi udara menurut WHO (2017) telah menjadi penyebab meninggalnya 570.000 anak setiap tahun karena infeksi saluran pernapasan, lebih dari setengah dari jumlah tersebut terjadi di negara-negara miskin dan negara berkembang. Menurut Villareal et. al (2008) polusi udara dari kendaraan bermotor telah menyebabkan radang saluran napas akut dan penurunan fungsi paru pada anak sekolah di Mexico City. Dampak polusi udara dari lalulintas juga diungkap oleh Schultz et al. (2012) yakni paparan polusi udara saat umur kanak-kanak mempengaruhi fungsi paru pada anak sampai dengan 8 tahun.

Saat ini pemerintah sedang giatnya mempersiapkan generasi emas 2045, dimana ditahun tersebut Indonesia diyakini akan mengalami siklus kejayan kembali dengan bonus demografinya (Sugiharto, 2012). Dalam menyosong generasi emas tahun 2045 tersebut langkah yang harus dilakukan diantaranya adalah menurunkan kematian anak dan memastikan kelestarian lingkungan hidup. Pertambahan jumlah kendaraan beberapa tahun belakangan ini akan memicu turunnya kualitas udara terutama di daerah perkotaan. Di kota Kendari peningkatan jumlah kendaraan disinyalir menjadi penyebab meningkatnya jumlah $\mathrm{SO}_{2}$ dan $\mathrm{PM}_{10}$. Parameter $\mathrm{SO}_{2}$ pada tahun 2014 sebesar $127.97 \mu \mathrm{g} / \mathrm{Nm}^{3}$ dan tahun 2015 sebesar 219, $4 \mu \mathrm{g} / \mathrm{Nm}^{3}$ atau meningkat sebesar 41,7\%. Parameter $\mathrm{PM}_{10}$ pada tahun 2014 sebesar $119.14 \mu \mathrm{g} / \mathrm{Nm}^{3}$ dan tahun 2015 sebesar 184,6 $\mu \mathrm{g} / \mathrm{Nm}^{3}$ meningkat sebesar 35,47\% (BLH Sultra, 2015). Sekolah-sekolah yang berada di pinggiran jalan perkotaan disinyalir akan mendapatkan dampak yang serius pula sehingga akan mengancam kesehatan anakanak di sekolah-sekolah tersebut sehingga keberlanjutan generasi akan terganggu. 
Tidak hanya fisiologi manusia, penurunan kualitas udara dapat mempengaruhi fisiologis tumbuhan. Tumbuhan lebih responsive terhadap perubahan lingkungan, sehingga dapat dijadikan indikator biologi. Salah satu indikator biologi yang diakui sensitive terhadap penuruan kualitas udara adalah Epiphytic lichen (Blasco et. al, 2011). Sensivitas lichen dalam penurunan kualitas udara dapat ditunjukkan dengan penurunan keragaman, terjadinya perubahan morfologi, fisiologis dan anatomis yang disertai hilangnya spesies yang sensitif (Bajpai et. al, 2010). Terpaparnya atmosfer oleh polutan toksik dalam jumlah besar terutama $\mathrm{SO}_{2}$ dan $\mathrm{NO}_{x}$ pada daerah perkotaan menyebabkan hilangnya secara dramatis mayoritas spesies epiphytic di kota-kota dunia (Adamo et. al, 2008). Warna ephypitic lichen pucat bahkan mati dan persentase kehadiran lichen sedikit pada persimpangan jalan dengan volume lalulintas tinggi (Sumarlin dan Dikman, 2017).

Kontrol kualitas udara perkotaan sebagai tindakan preventif untuk mengatasi masalah kesehatan masyarakat terutama anak-anak karena organnya belum sesempurna orang dewasa harus secara kontinu dilakukan. Kontrol kualitas udara dengan menggunakan alat monitor membutuhkan sumberdaya yang tidak sedikit, sementara indikator biologi dianggap dapat menggambarkan karakteristik dampak (Holt dan Miller, 2011), dan lebih efisen dibandingan dengan alat monitor.

\section{METODE PENELITIAN}

Penelitian ini menggunakan pendekatan kuantitatif dengan metode survey sebagian anggota populasi yang ditentukan secara purposive sampling yang diharapkan merepresentasikan populasi. Variabel yang diamati dan diukur adalah volume lalulintas dan epiphytic lichen. Penentuan lokasi penelitian mempertimbangkan aktivitas lalulintas perkotaan yang padat, sedang dan rendah yang akan berkaitan dengan kualitas udara. Adapun lokasi penelitian ini adalah SDN 18 Baruga (pinggiran kota), SDN 02 Baruga (pusat kota), SDN 01 Poasia (pengembangan kota). Waktu pengukuran kepadatan lalulintas mempertimbangkan kepadatan aktivitas lalulintas pekanan/hari yaitu hari senin (awal pekan), hari rabu (tengah pekan), hari jum'at (akhir pekan) dan kepadatan aktivitas harian/jam yaitu pukul 06.3007.30 WITA (pagi), pukul 10.30-11.30 WITA (siang), dan pukul 15.30-16.30 WITA (sore). Karakteristik epiphytic lichen diamati pada vegetasi sekolah berdiameter minimal $5 \mathrm{~cm}$ dengan ketinggian 1 meter dari permukaan tanah dengan jarak 5 meter, 20 meter, 35 meter dari pinggir jalan raya. Gambaran variabel dan informasi yang didapatkan dalam penelitian 
ini kemudian dideskripsikan secara kualitatif. Bagan alur (flowchart) metode penelitian ini dapat diilustrasikan pada gambar sebagai berikut.

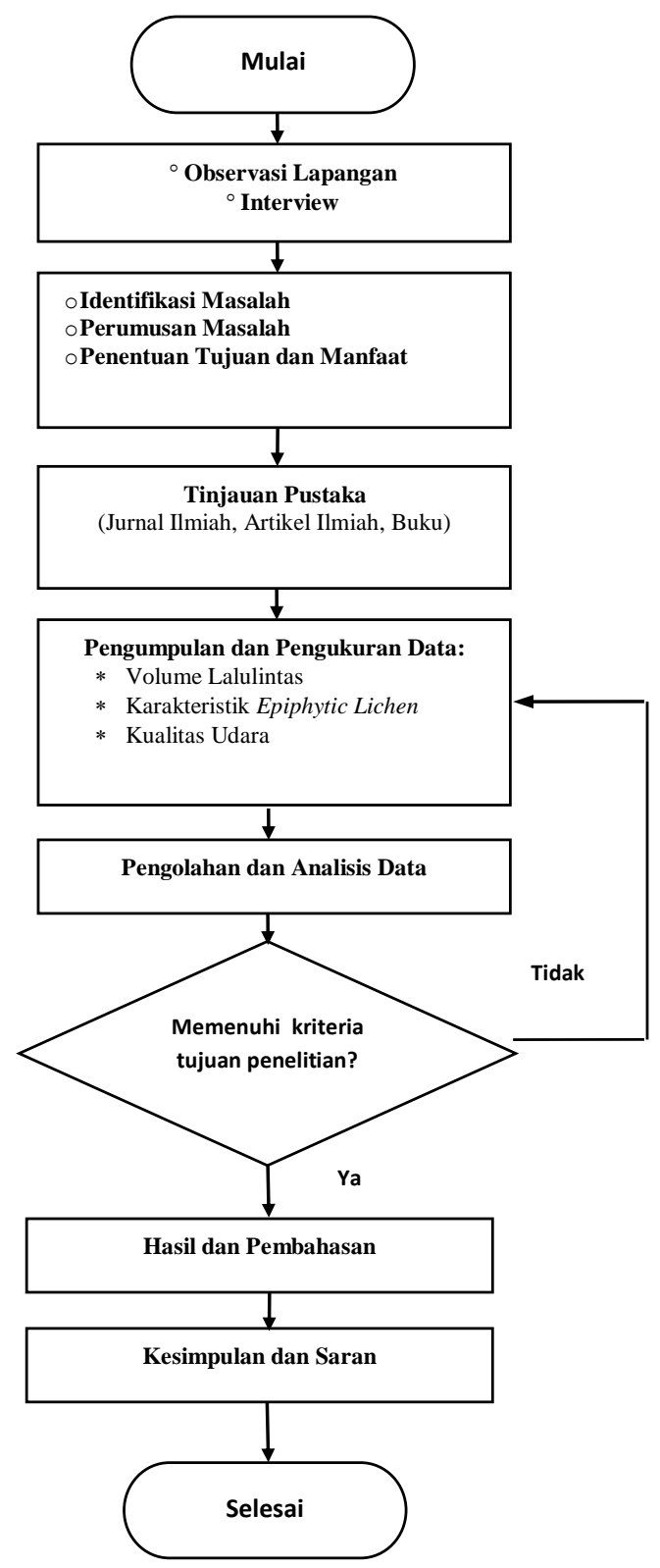

Gambar. 1 Flowchart Penelitian

\section{HASIL DAN PEMBAHASAN}

Pemantauan jumlah maksimum kendaraan yang melewati 3 (tiga) titik diketahui volume lalulintas harian yang melewati SD Negeri 1 Poasia sebanyak 8.065 kend/hari, volume lalulintas harian yang melewati SD Negeri 2 Baruga sebanyak 7.948 kend/hari dan volume lalulintas harian yang melewati SD Negeri 18 Baruga sebanyak 366 kend/hari. Hal ini menunjukkan bahwa volume lalulintas harian tertinggi terjadi pada jalan di depan SDN 1 Poasia dan terendah terjadi di SD Negeri 18 Baruga. Sementara itu, kehadiran lichen pada 
vegetasi di SD Negeri Poasia mencapai $66 \%$ dengan persentase luas penutupan lichen sebesar 20\%, kehadiran lichen pada vegetasi di SD Negeri 2 Baruga mencapai $67 \%$ dengan persentase luas penutupan lichen sebesar $21 \%$ dan kehadiran lichen pada vegetasi di SD Negeri 18 Baruga mencapai 100\% dengan persentase luas penutupan lichen sebesar $90 \%$. Karakteristik talus lichen yang ditemukan secara umum dikelompokan 2 (dua) tipe bentukan yakni bentukan seperti daun, datar, lebar, banyak lekukan seperti daun yang mengkerut berputar, dan bentukan seperti bercak putih, melekat erat pada kulit pohon (substrat), datar dan tipis permukaannya. Menurut Nash (2008), lichen yang melekat erat pada subsrat dan mungkin tidak bisa hilang karena permukaannya tipis adalah karakteristik lichen tipe crustose, sedangkan lichen yang hanya melekat sebagian pada subrat, datar dan seperti daun adalah ciri dari lumut tipe foliese. Berdasarkan hal tersebut ini berarti, tipe lichen yang ditemukan pada 3 titik pemantauan adalah tipe foliese dan tipe crustose. Menurut Consorsium North America Lichen Herbarium (2016) menyatakan famili Graphidaceae dan Arthoniceae yang termasuk lichen tipe crustose (www.lichenportal. org). Menurut Thower (1988) ciri dari family graphidaceae adalah polanya unik seperti hieroglyph, memanjang, bentuk askus linier, elongate,

Hubungan antara volume lalulintas dengan prosentase kehadiran lichen pada setiap titik pengamatan diuji dengan menggunakan Spearman's rank correlation dan didapatkan koefisien korelasi $\left(r_{s}\right)=-1,00$ dan probabilitas hitung $\left(\mathrm{P}_{\text {value }}\right)=0,0$; dikarenakan nilai hitung $\left(\mathrm{P}_{\text {value }}\right)$ lebih kecil dari nilai signifikasi $(\alpha)=0,01$ maka $\mathrm{H}_{0}: \rho_{\mathrm{s}}=0$ ditolak, ini artinya, ada korelasi antara tingginya volume kendaraan dengan prosentase kehadiran lichen di sekolah-sekolah pinggir jalan. Korelasi antara volume lalulintas dengan prosentase kehadiran lichen dapat dilihat pada Gambar. 2 berikut ini.

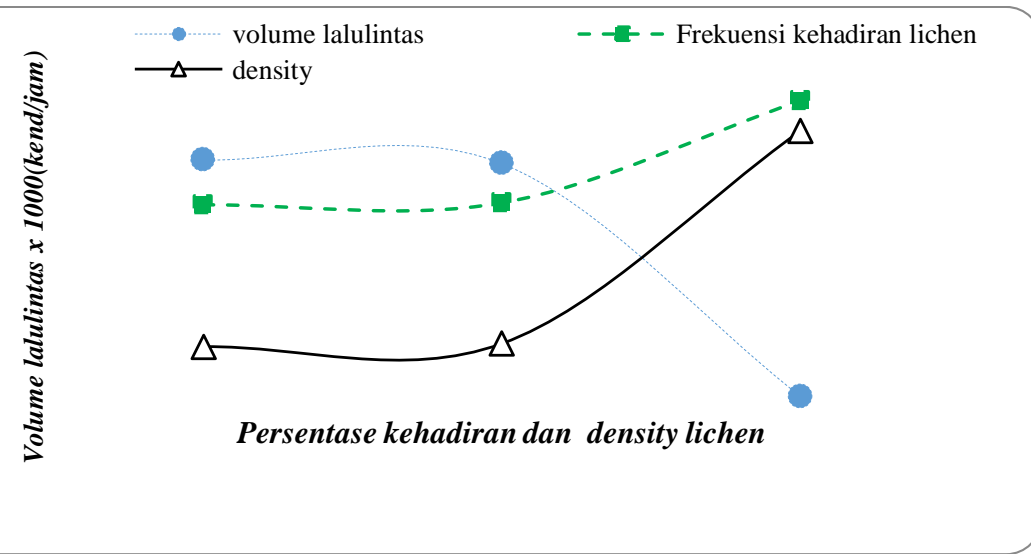

Gambar 2. Grafik antara volume lalulintas dan kehadiran lichen 
Berdasarkan Gambar 2 menunjukkan bahwa semakin tinggi volume lalulintas maka maka presentase kehadiran lichen semakin rendah. Volume lalulintas yang tinggi di yang melintasi sekolah dasar memungkinkan terjadinya pencemaran udara, Noer dalam Pratiwi (2006) menjelaskan parameter yang digunakan untuk mengungkapkan terjadinya pencemaran udara dengan menggunakan lichen sebagai bioindikator adalah pada daerah dimana pencemaran telah terjadi, jumlah jenis yang ada sedikit dan jenis-jenis yang peka sekali akan hilang. Pada area dimana volume lalulintas tinggi jumlah polutan gas buang dari kendaraan konsentrasinya akan tinggi karena terakumulasi secara intens dan periodik setiap saat. Menurut Sumarlin dan Maheng (2017), perbedaan tampakan warna epiphytic lichen dihubungkan dengan volume kendaraan dapat dilihat pada gambar berikut.

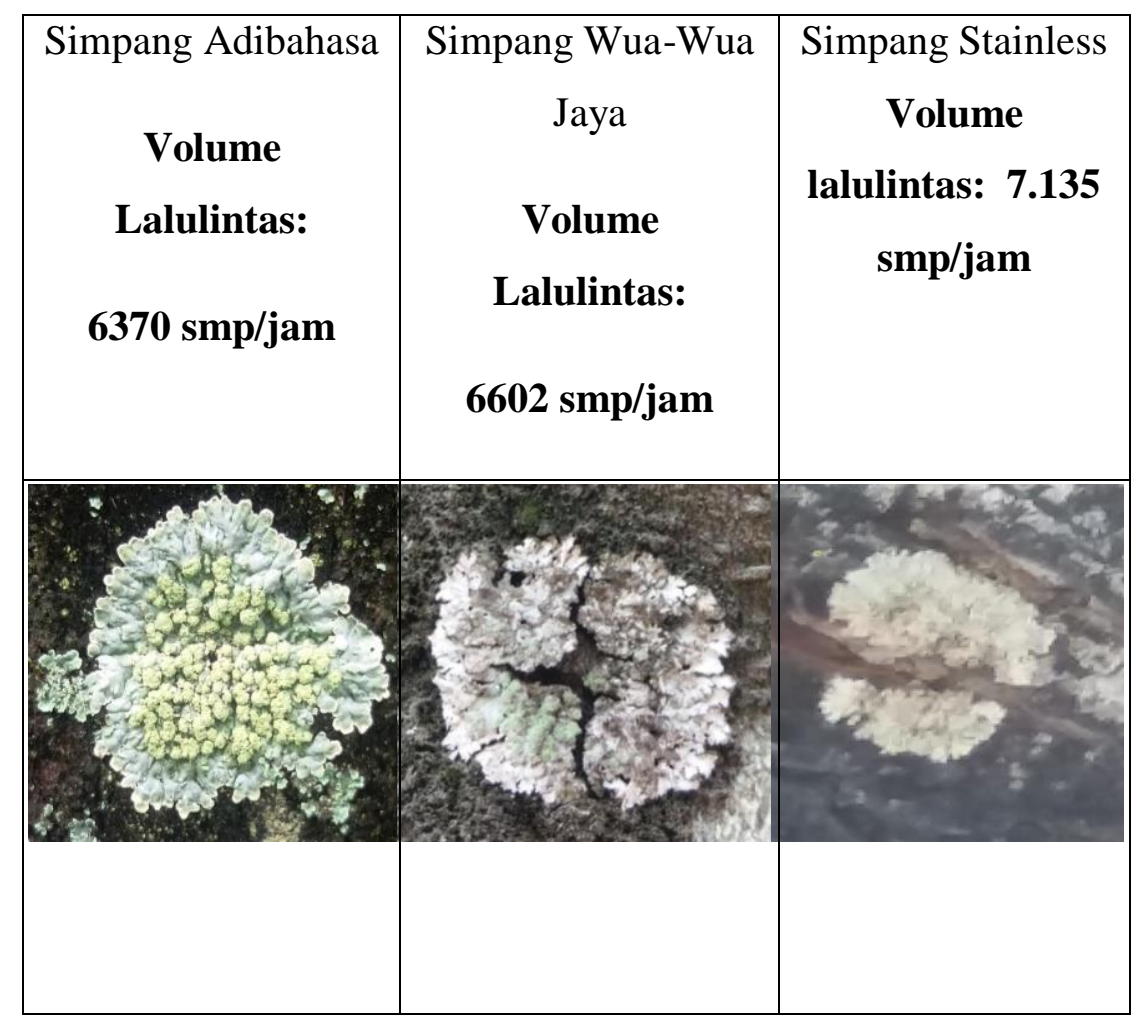

Gambar 5.7 Tampakan parmelia. sp pada 3 (tiga) titik pemantauan (Sumber: Sumarlin \& Maheng, 2016)

Menurut Sumarlin dan Maheng (2017), menyatakan bahwa semakin tinggi volume kendaraan warna lichen semakin berubah, lichen di daerah yang tercemar pertumbuhannya kurang baik, warnanya pucat atau berubah. Adapun tampakan lichen pada titik pengamatan dapat dilihat pada gambar 3 berikut ini. 


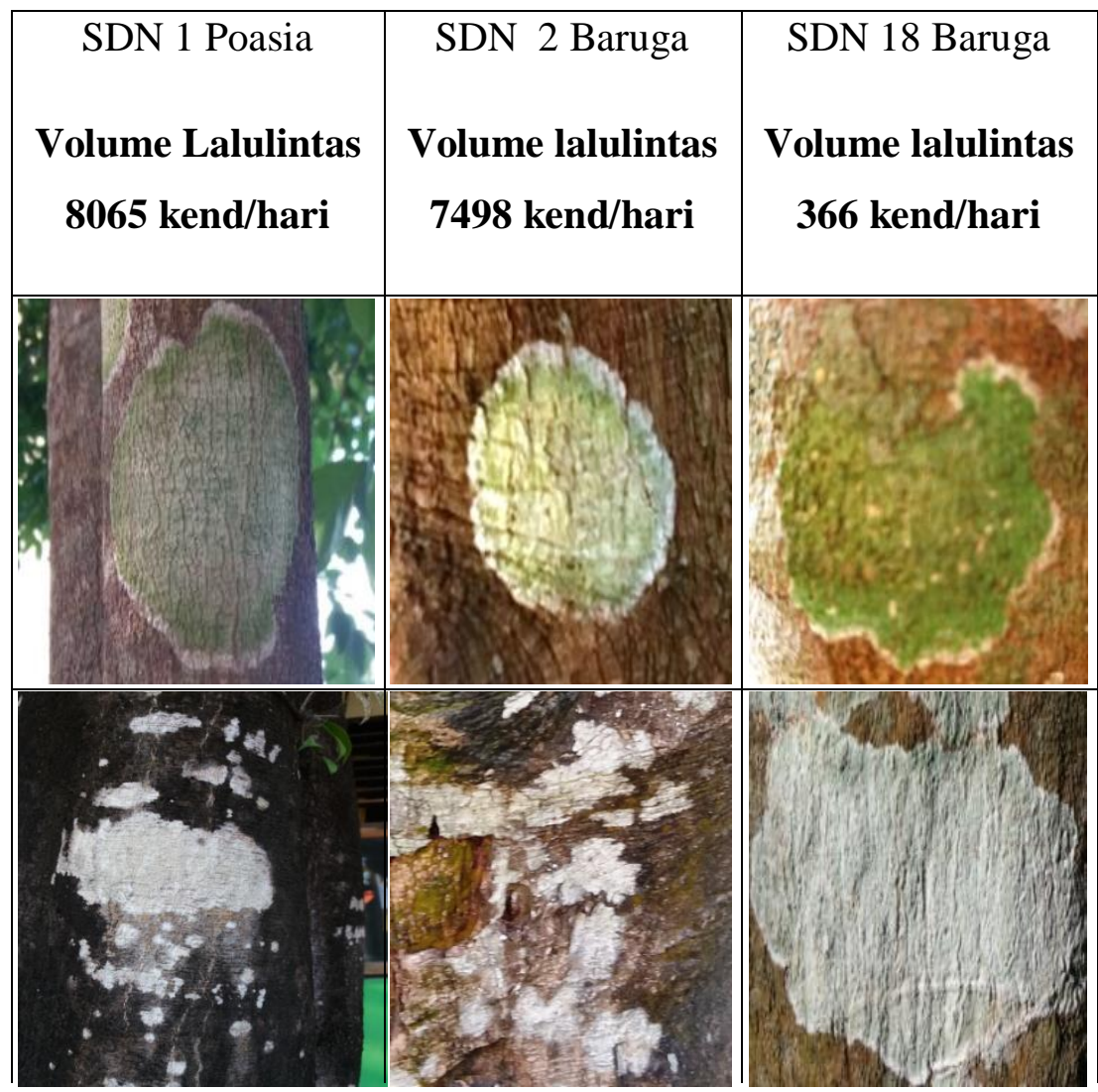

Gambar 5.8 Tampakan Cryptothecia striata (atas) dan

Graphis.sp (bawah) pada tiga titik pemantauan.

Berdasarkan tampakan talus lichen di atas area dengan volume lalulintas tinggi berbeda dengan tampakan lichen dengan volume lalulintas rendah, semakin sedikit volume lalulintas maka warna talus semakin terang begitupun pertumbuhan lichen. Berdasarkan spesiesnya lichen yang ditemukan di SDN 1 Poasia dan SDN 1 Baruga tergolong dalam spesies graphidaceae dan arthoniceae, berdasarkan Syamsudin et.all (2012) spesies ini moderat dengan adanya polutan dan dapat hidup area dengan pencemaran sedang dan berpotensi tercemar berat sedangkan di SD 18 Baruga masih ditemukan spesies yang sensitif dengan polutan (spesies physcia, sp) hal ini menujukkan bahwa lingkungan SDN 18 Baruga berada pada taraf lingkungan udara bersih berpotensi tercemar ringan.

\section{KESIMPULAN}

Penilaian kualitas udara menggunakan epiphytic lichen pada sekolah pinggir jalan perkotaan, hasil pemgamatan menujukkan ada korelasi antara tingginya volume kendaraan dengan prosentase kehadiran lichen di sekolah-sekolah pinggir jalan dan semakin tinggi volume lalulintas yang melewati suatu sekolah maka pertumbuhan epiphytic lichen semakin tidak subur, talus tipis dan warna pucat. Gas buang dari kendaraan bermotor yang intens dan periodik memungkinkan menurunnya prosentase kehadiran lichen dan perubahan 
pertumbuhan serta warna epiphytic lichen di titik pengamatan. Hal ini sangat berkaitan erat dengan penurunan kualitas udara di sekolah-sekolah pinggir jalan, berdasarkan karakteristik tampakan epiphytic lichen di lokasi pemantauan menujukkan bahwa pada lingkungan SDN 1 Poasia dan SDN 2 Baruga telah tercemar sedang dan berpotensi tercemar berat sedangkan pada lingkungan SDN 18 Baruga masih dalam taraf udara bersih dan berpotensi tercemar ringan.

\section{SARAN}

Penelitian selanjutnya dapat dilaksanakan dengan mempertimbangkan lokasi dan kuantitas pengambilan data dengan jangka waktu yang lebih lama.

\section{UCAPAN TERIMA KASIH}

Terimakasih kepada Direktorat Riset dan Pengabdian Masyarakat Direktorat Jenderal Penguatan Riset dan Pengembangan Kementerian Riset, Teknologi dan Pendidikan Tinggi yang telah membiaya ini penelitian ini serta Lembaga Penelitian dan Pengabdian Masyarakat Universitas Muhammadiyah Kendari atas kerjasama selama berlangsungnya penelitian ini.

\section{DAFTAR PUSTAKA}

Adamo. P, Bargagli. R, Giordano. S, et. al., 2008. Natural and pre-treatments induced variability in the chemical composition and morphology of lichens and mosses selected for active monitoring of airborne elements. Environ Pollut 152:11-19

Bajpai, R, Upreti, D.K, Nayaka S, Kumari, B., 2010. Biodiversity, bioaccumulation and physiological changes in lichens growing in the vicinity of coal-based thermal power plant of of Raebareli district, north India. Journal Hazard Mater 174:429-436

BLH (Badan Lingkungan Hidup) Kota Kendari, 2015. Laporan Evaluasi Kualitas Udara Perkotaan, Tahun 2015 Badan Lingkungan Hidup Sulawesi Tenggara, Kendari

Blasco, M., Domeno., C, Lopez. P., Nerın, C. 2011. Behaviour of different lichen species as biomonitors of air pollution by PAHs in natural ecosystems. Journal Environment Monitor 13:2588

EEA (European Environmental Agency): European Union emission inventory report 19902012 under the UNECE Convention on Long-range Ransboundary Air Pollution 
(LRTAP), Annex I, European Union (EU-27) LRTAP emission data (http://www.eea.europa.eu/publications/lrtap-2017, diakses: 10 Maret 2017)

Holt, E.A,. Miller, S.W., 2011. Bioindicators: using organisms to measure environmental impacts. Nature Education Knowledge (diakses, 10 Januari 2016)

http://www.lichens.ie/lichens-as-biomonitors/( diakses: 11 Maret, 2017)

Indayani, K.,Kirya, I.K., Yulianthini, N.N,. 2014. Analisis faktor-faktor yang mempengaruhi keputusan konsumen dalam membeli mobil. e-Journal Bisma. Universitas Ganesha Jurusan Managemen. Volume. 2

MEP (Ministry of Environmental Protection, P. R. China): Bulletin of China's Environmental Status in 2013, ( http://jcs. mep.gov.cn/hjzl/zkgb/2013zkgb, diakses: 20 Maret 2017)

Pratiwi, M. E., 2006. Kajian lichen sebagai bioindikator kualitas udara studi kasus: kawasan industri Pulo Gadung, Arboretum Cibubur dan tegakan mahoni Cikabayan. Skripsi. IPB, Bogor.

Samsuddin, MW., Din, L., Zakaria, Z,. Latip, at.al., 2012. Measuring air Quality Using Lichen mapping at Universiti Kebangsaan Malaysia (UKM) Campus. Procedia-Sosial and Behavorial Sciences. 655-643.

Saputra, D., A. 2013. Pengaruh Kualitas produk, Harga, dan Iklan terhadap Keputusan Pembelian Sepeda Motor Yamaha. Naskah Publikasi Ilmiah. Prodi Manajemen Fak. Ekonomi UMS. Solo.

Sugiharto, 2012. Menyongsong Indonesia Emas 2045 Disampaikan pada Kuliah Perdana Universitas Sarjanawiyata Tamansiswa (UST) Yogyakarta. Tanggal 17 September 2013 (https://lutfiyah17.files.wordpress.com/2013/01/

Sumarlin, M.M. Dikaman, 2017. Pendeteksian Kualitas Udara Perkotaan Melalui Karakteristik Epiphytic Lichen Pada Persimpangan Jalan. Laporan Penelitian. Universitas Muhammadiyah Kendari

Schultz, Erica.S., Gruzieva, O., Bellander, T., Bottai, M, et.al, 2012. Traffic-related Air Pollution and Lung Function in Children at 8 Years Age. American Journal of Respiratory and Critical Care Medicine. Vol 186 pp: 1286-129. 
US. EPA (United States Environmental Proction Agency), 2014. The 2014 National emissions Inventory (http: //www.epa.gov/ttn/chief/net/2014 inventory. Html (diakses: 30 April 2017)

Villareal, A.B., Sunyer, J., Cadena, L.H., Nunez, M.C.E,. 2008. Air Pollution, Airway Inflammation, and Lung Function in Cohort Study of Mexico City Schollchildren. Research. Environmental Health Perspectives. Vol. 116 (6) pp 832-838

Winarti, E.Ch. 2015. Pengaruh Motivasi Konsumen, Persepsi Kualitas, Sikap Konsumen dan Harga terhadap Keputusan Pembelian Mobil Nissan Grand Livina di Dealer Pusat PT. Nissan Motor Indonesia, JL. MT. Haryono Kav. 10 Jakarta Timur. Kelola Vol. 2. No. 3 (ISSN: 2337-5965)

WHO, 2017. Health and Air Pollution (http://www.who.int/mediacentre/factsheets, diakses: 11 April 2017 